\section{Production of 'Endomitosis' in Bean Roots and its Bearing on the Genesis of Tumours}

Biesele, Poyner and Painter have shown ${ }^{1}$ that diplochromosomes and higher polytenes are often to be found in tumours and that these large chromosomes are the result of endomitosis. Biesele and Cowdry $^{2}$ also found these abnormalities in the epidermis of mice painted with methylcholanthrene, as early as two days after painting.

Recently, using bean roots, endomitosis was found by chance in roots allowed to become partially dry. Following up this observation, it was found that exposure to a colloidal suspension of benzpyrene and to hypertonic sugar solution also gave rise to this change.

I use the term 'endomitosis' because it was used by Biesele and others to describer their findings. They found fully condensed chromosomes in nuclei having intact walls. The figure below shows similar abnormalities in treated bean roots.

The details of treatment were as follows. For partial drying, use a root about $20 \mathrm{~cm}$. long-to obtain this length it is necessary to remove all lateral roots-pass it down glass tubing so that only $2 \mathrm{~cm}$. are immersed in distilled water; leave it thus for 12 hours and then examine histologically. For benzpyrene treatment, substitute for the distilled water a colloidal suspension of 0.05 per cent in distilled water (good suspensions cannot be made in the presence of salts); under these conditions, the action of benzpyrene and of partial drying are combined, and abundant endomitoses are produced. Benzpyrene treatment without partial drying is obtained by filling the tubing to the top with colloid, but longer exposures of 24-48 hours are required. The effect is not obtained with short roots and before leaves have formed; it seems that an abundant volume of water must be absorbed-and this does not occur with short roots-for a sufficient amount of benzpyrene to enter. The suspended particles do not appear to enter, but only benzpyrene in solution. Occasional endomitoses were obtained by placing the roots in 8-10 per cent dextrose.

It is to be noted that two of the agents are potent to produce increased viscosity of the cytoplasm; as regards benzpyrene, information is wanting. Further, Guyer and Claus, using the ultracentrifuge, have shown ${ }^{3}$ that tumour cells present great stiffening of the cytoplasm in comparison to cells of normal tissues, and that this applies not only to experimentally produced hepatomas, but also to liver cells in pre-cancerous stages.

It is likely, therefore, that endomitosis, polytene, polyploid and polynuclear cells of tumours are
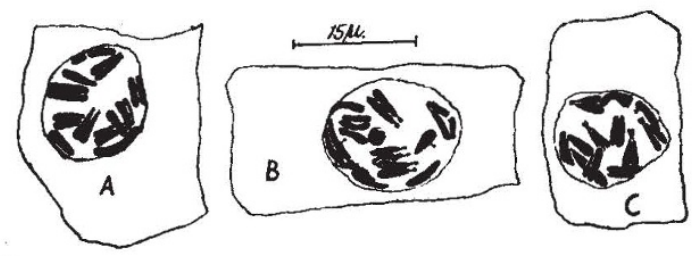

THE FIGURE SHOWS THREE CELLS FROM ROOT TIP OF BEANS, STAINED WITH IODINE GENTIAN VIOLET: $A$, TREATED FOR 20 HOURS
WITH BENZPYRENE; $B$, FOR 12 HOURS BY PARTIAL DRYING; $A$ ND W. WITH 8 PER CENT DEXTROSE FOR 24 HOURS. THE CHROMOSOMES $C$, WITH 8 PER CENT DEXTROSE FOR 24 HOURS. THE CHROMOSOMES
$(2 n=12)$ ARE ABNORMALLY CONDENSED AND THE CHROMATIDS CLOSELY APPLIED AS IN LATE METAPHASE. AT THE SAME TMME A FINE NUCLEAR WAIIL IS PRESENT. IN $B$ THE NUCLEOIUUS HAS NOT BEEN ENTIRELY ABSORBED. IN $A$ AND $B$ THE CENTRONERES APPRAR
TO HAVE DIVIDED AND IN $C$ TO BE UNDIVIDED. IN $B$ AND $C$, TO HAVE DIVIDED AND IN $C$ TO BE UNDIVIDED.
LATERAL TRABANTS ARE PRESENT. secondary to an increased stiffness of the cytoplasm and no more than signs of such a change.

Increased viscosity of the cytoplasm was observed 4 as a common reaction of ciliates to a wide range of tumour-producing agents, and led to races of multiple organisms.

Mount Vernon Hospital,

J. C. Mottram.

Northwood, Middx.

Nov. 2.

${ }^{1}$ Biesele, J. J., Poyner, H., and Painter, T. S., Univ. Texas Publ. No. 4243 (1942).

${ }^{2}$ Biesele, J. J., and Cowdry, E. V., J. Nat. Cancer Inst., 4, 373 (1944).

s Guyer, M. F., and Claus, P. E., Proc. Soc. Exp. Biol. and Med., 35, 568 (1936); Anat. Rec., 73, 17 (1937); Canc. Res., 2, 16 (1941).

"Mottram, J. C., "The Problem of Tumours" (London: Lewis and Co., Ltd., 1942).

\section{Effect of some Pure Substances on Plant Growth}

INCREASING concentration of heteroauxin in lanolin - water paste causes progressive inhibition of the growth of hypocotyls of dark-grown Helianthus seedlings. At moderate concentrations definite swellings are produced. These effects can be considered as being the result of a progressive disorientation of the cytoskeleton with corresponding loss of cell polarity. A higher degree of disorganization would naturally lead to autolysis. In the presence of the sodium salts of alizarin and quinizarin sulphonic acids, the above effects can be so modified that it requires a higher concentration of heteroauxin to produce an effect similar to that produced with lower concentrations of heteroauxin alone. Tests with the alizarin sulphonate indicate that in aqueous solu. tion it does not destroy heteroauxin to any great extent when this is estimated colorimetrically.

The growth of oat roots can be inhibited by $0-, m$. and $p$-phenylene-diamine, benzidene, benzoquinone and other substances, these simultaneously staining the cell wall. In an extremely dilute solution of phenanthraquinone, roots gave a growth value only 16 per cent of those grown in tap water. Gallic and di-gallic acids in 0.01 per cent solution gave values of about 50 per cent. These substances have the property of reacting with proteins and would act as molecular cross-linkages ${ }^{1}$ between the proteins of the embryonic cells of the root tip, thus preventing development of the normal dynamic cytoskeleton.

On a hypothesis that auxin by some means dis. engages certain bonds of attachment between the proteins or components of the cytoskeleton, the various effects of auxins become more understand. able. Normal extension of a cell would result from the action of auxins on the three-dimensional lattices ${ }^{2,3}$ of the cell wall and cytoskeleton. An artificial cyto. skeleton such as would be formed in the root tips with some protein reactants would be stable and non. reactive to auxins. It is possible that alizarin and quinizarin sulphonic acids act more selectively on the hypocotyl cells.

Department of Plant Physiology,

R. Forbes Jones.

Hosa Research Laboratories, Sunbury-on-Thames. Nov. 8.

${ }^{1}$ Powell, A. K., Nature, 158, 345 (1944).

¿ Frey-Wyssling, A., Science Progress, 34, 249 (1939).

3 Needham, J., "Biochemistry and Morphogenesis" (Cambridge, 1942). 